\title{
Motivational Change After Curricular Revision: Intersections With Out-of-Class Time Use
}

\section{Brad Visgatis \\ Osaka International University}

\section{Tamara Swenson}

Osaka Jogakuin University

\section{Reference Data}

Visgatis, B., \& Swenson, T. (2021). Motivational change after curricular revision: Intersections with out-of-class time use. In P. Clements, R. Derrah, \& P. Ferguson (Eds.), Communities of teachers \& learners. JALT. https://doi.org/10.37546/JALTPCP2020-17

This paper reports on changes in the motivation and out-of-class time allocation to English by students at one university in Western Japan following curricular revision. Changes to the English curriculum made beginning in the 2012 academic year included a redistribution and increase in writing class hours, a shift to ebooks for first-year content-based materials, an introduction of an online extensive reading program for first-year students, and the implementation of receptive and productive vocabulary testing in first- through third-year courses. Data from a motivational survey in Japanese and time use diaries were collected from participants in 2018 and compared to previous data from 2011. No significant difference was found between the two groups in the participants' motivational profiles or amount of out-of-class time allocation to English. Some important differences were found in how time was allocated, yet total study hours outside-of-class fall short of program and governmental expectations.

本稿は、西日本の大学に在学する学生の教室外での英語学習の時間配分と英語学習動機の関係についての研究報告であ る。対象大学では英語かリキュラムの改訂が2012年から実施された。改訂内容は、ライテイングの時間の増加と再配分、初年 度の学生へのコンテントベースクラスの読解教材の電子書籍化とオンラインでの多読プログラムの導入、1 3年次を通した 受容語彙と産出語彙のテストの導入等であった。日本語による英語学習動機付けの調査と日記のデータを収集し英語カリキ ユラム改定後の2018年と改訂前の2011年で比較した。その結果、参加者の教室外での英語学習動機プロフアイルおよび英語 学習時間数において有意差は見られなかった。一方、学習時間の配分に関しては重要な差が見られたが、教室外の総学習時 間量は、大学および文部科学省の期待值に及ばない結果となった。 tudent outcomes remain a constant concern for language educators at Japanese $\checkmark$ universities. To improve outcomes, schools can change the curriculum and leverage technology to make the learning process more efficient and adjust the content and skills to be mastered to better suit student and societal needs. One particular aim of curricular revision is to increase learning motivation and, along with that, the time students spend engaged in learning. The amount of time that students are exposed to or spend on studying English is considered by many to be the factor that has the greatest impact upon their language proficiency (Hyland, 2004; Kuh, 1995; Visgatis, 2014).

School programs are designed to provide students with a set number of structured contact hours. In addition, out-of-class time on study or use of the language is expected by teachers, program administrators, and national bodies. For college and university students in Japan, students are expected to spend twice as much time outside of class on study than in class for most courses, a 2:1 ratio in line with university requirements in other countries (MEXT, 2009; Visgatis, 2014). However, not only is there great variability in the amount of time students actually spend studying for class, they also engage with English in a variety of ways, including study for extracurricular proficiency exams, consumption of English media for pleasure, participation in English-related clubs or contests, and interacting with others at part-time jobs or in their daily lives (Visgatis, 2014). The degree to which students engage in these is partly determined by opportunity, other obligations, and individual motivation.

The links between time use and motivation in language learning have been pointed out (e.g., Boo et al., 2015; Dörnyei et al., 2015; Woodrow, 2017), and researchers have begun to explore these same links in Japan (Visgatis, 2014) and other countries (e.g., Oga-Baldwin \& Fryer, 2020). A full review of the research on motivation and time use is beyond the scope of this paper, but in addition to the research already mentioned, those interested in the intersections should explore Busse \& Walter (2013) and Ushioda $(2011,2020)$. That motivation and time use are linked is clear, but the difficulty in conducting research on the intersections between these two concepts leaves numerous gaps in our knowledge. 
The aim of this paper is to present results from a comparison of language learning motivation and out-of-class English-related time use among Japanese university students at a private women's university prior to and subsequent of curricular changes. First, we describe the curricular changes and rationale behind them, then we discuss results from data collected through a language learning motivational survey and time use diaries.

\section{Curricular Change}

A series of curricular changes were phased in over a two-year period at a private women's university and college in Japan. The aims of the changes were to (a) leverage technology, (b) increase learning motivation, (c) refocus study time, and (d) increase time spent studying. The changes included several innovations, such as providing each student with a tablet computer (iPad) and to move faculty-developed first-year course materials to the iBook format (e.g., Cline et al., 2017; McCarty et al., 2017; Swenson et al., 2014). The content focus of the materials remained the same, but listening materials, audio-visual lectures, and interactive activities were added. (See Swenson et al., 2014, for a discussion of the development of these materials.)

Table 1 provides an overview of the changes for required English courses and Table 2 indicates differences in the required components for English courses between the 2011 and 2018 curricula. The changes included a switch to 90 -minute periods, versus 50 minutes in 2011, which necessitated changes to in-class time allocation for all years.

Table 1

Changes Made to Curriculum for Required English Courses

\begin{tabular}{lrl}
\hline Year & Change & \multicolumn{1}{c}{ Details } \\
\hline $\begin{array}{l}\text { First- } \\
\text { year }\end{array}$ & Reduced & $\begin{array}{l}\text { Writing courses cut to once a week (30 meetings x 90 minutes } \\
\text { versus 60 meetings x 50 minutes), } 2 \text { credits per term }\end{array}$ \\
$\begin{array}{l}\text { Second- } \\
\text { year }\end{array}$ & Added & $\begin{array}{l}\text { Academic writing course (15 weeks x } 90 \text { minutes), } 2 \text { credits } \\
\text { Academic discussion course (15 weeks x } 90 \text { minutes), } 2 \text { credits }\end{array}$ \\
& Retained & $\begin{array}{l}\text { World news course (30 weeks x } 90 \text { minutes), } 2 \text { credits per term } \\
\text { Content-based English courses (4 courses x 15 weeks x 90 } \\
\text { minutes), 2 credits per course, two courses per term }\end{array}$ \\
\hline
\end{tabular}

\begin{tabular}{lll}
\hline Year & Change & \multicolumn{1}{c}{ Details } \\
$\begin{array}{l}\text { Third- \& } \\
\text { fourth- } \\
\text { year }\end{array}$ & Added & $\begin{array}{l}\text { Research and presentation course (15 weeks x 90 minutes), } 2 \\
\text { credits } \\
\text { Research writing course (15 weeks x 90 minutes), 2 credits }\end{array}$ \\
& $\begin{array}{l}\text { Retained } \\
\text { Content-based major courses in English for third \& fourth year } \\
\text { students (2018: five courses x 15 weeks x 180 minutes; 2011: five } \\
\text { courses x 15 weeks x 150 minutes), increased credits per course } \\
\text { from 3 to 4 } \\
\text { English graduation thesis course (30 weeks x 90 minutes, with } \\
\text { additional time expected on research and with thesis advisor), } 6 \\
\text { credits }\end{array}$ \\
&
\end{tabular}

Table 2

Differences in the Curriculum Between 2011 and 2018

\begin{tabular}{|c|c|c|}
\hline Area Changed & 2011 & 2018 \\
\hline \multirow{2}{*}{$\begin{array}{l}\text { Contact hours } \\
\text { (required) each } \\
\text { week }\end{array}$} & $\begin{array}{l}11.5 \text { hours (first year), } 12 \\
\text { credits per term; }\end{array}$ & $\begin{array}{l}10.5 \text { hours (first year), } 12 \text { credits per } \\
\text { term; }\end{array}$ \\
\hline & $\begin{array}{l}4.5+(\text { second year }), 6 \\
\text { credits per term }\end{array}$ & $\begin{array}{l}6+\text { (second year), } 6 \text { credits per term; } \\
1.5+\text { (third year), } 2 \text { credits per term }\end{array}$ \\
\hline Technology & iPods \& paper texts & iPads \& digital texts \\
\hline First-year texts & \multicolumn{2}{|c|}{$\begin{array}{l}\text { focus of faculty-developed texts identical, revised and updated: } \\
\text { Identity \& values; Peace \& conflict; Human rights; Environment }\end{array}$} \\
\hline \multirow[t]{2}{*}{ Components } & ER optional (print) & ER required ( $10 \%$ of grade); \\
\hline & Vocabulary, set by teachers & $\begin{array}{l}\text { Vocabulary program (receptive and } \\
\text { productive) required ( } 10 \% \text { of grade) }\end{array}$ \\
\hline Writing courses & 180 min., first year only & 270 min., first to third year \\
\hline $\begin{array}{l}\text { Discussion } \\
\text { courses }\end{array}$ & 180 min., first year only & 360 min., first to third year \\
\hline
\end{tabular}

Note. ER $=$ Extensive reading, $\min .=$ minutes 
Components of individual courses were also changed. Two key changes were the implementation of a required extensive reading program in first-year courses (e.g., Lyddon \& Kramer, 2019; Nation \& Waring, 2019) and a receptive and productive vocabulary program with cumulative testing in first- through third-year reading, discussion, and writing courses (e.g., Kramer et al., 2019; McLean et al, 2013; Nakata et al, 2020). Extensive reading (first-year) and vocabulary (first- to third-year) components were piloted and integrated as required components of courses in 2018.

\section{Evaluating the Impact of Curricular Change}

Although there are many ways to assess the impact of curricular change, this paper focuses on two broad areas: out-of-class time use and learner motivation. Prior to the curricular changes in 2012, Visgatis (2014) collected data on motivation and out-of-class English-related time use from 11 different sites, including this institution. Access to data collected between November, 2011 and January, 2012 (the "2011" data) led to a decision to conduct a partial replication of that study, using the same methodology for the time use and motivational data collections. The aim was to compare and contrast the time use and language learning motivation from both periods. The research questions for this project follow, along with one hypothesis.

\section{Research Questions}

Several research questions (RQs) and one hypothesis were proposed prior to the 2018 data collection. The RQs were as follows:

RQ1. Were significant differences observed in the degree of student motivation between the 2011 and 2018 datasets? If so, in which direction?

RQ2. How much time did students allocate to out-of-class English study in 2011? In 2018?

RQ3. Were there differences in the amount of out-of-class time use by students between these two years?

RQ4. What differences were observed in how students spent out-of-class time between 2011 and 2018?

RQ5. What proportion of students met the Ministry of Education in-class to out-of class study time ratios, and were there differences between the two years?

\section{Hypothesis}

1. Students in the 2018 study would spend more time in out-of-class study than those in the 2011 dataset.

Study of Motivation and Time Use: Comparison of 2011 and 2018

Motivation and time use were examined in detail by Visgatis (2014) at institutions throughout Japan. This data included information from participants at one private women's university in Western Japan, which is the site of the 2018 study. Data for the 2011 and 2018 participants are reported below.

\section{Participants}

All participants $(N=794)$ completed a motivational survey (see below) and a subset submitted time data $(2011: n=97 ; 2018: n=174)$. All participants were students in their first- through third-year of study at a women's university and had similar backgrounds. They had the same two majors, either English (college) or English and international studies (university). As such, they can be considered representative of the population of students at the institution.

\section{Informed Consent}

All the participants gave informed consent, and the project was cleared with the institutional review board (IRB) at the site of the 2011 and 2018 studies. The informed consent form was provided in Japanese to participants.

\section{Data Collection}

The same instruments were used to collect data for both time periods. These instruments, developed and validated by Visgatis (2014), are described below. They were distributed on paper to all first- through third-year students in 2011 and 2018. 
JALT2020

COMMUNITIES OF

\section{Motivational Data}

Before each of the time-use data collection periods in 2011 and 2018, participants completed the Japanese version of a motivational survey based upon Dörnyei’s (2009) Motivational Self System and reported in Visgatis (2014). The motivational survey targeted the following areas: Intention to Learn (eight items), Ideal L2 Self (eight items), Ought-to Self (nine items), Influence of Significant Others (nine items), Attitudes Toward Learning English (seven items), Attitudes Toward English Language and Culture (eight items), Instrumentality-Promotion (nine items), and Instrumentality-Prevention (six items).

\section{Out-of-class Time Use Data}

For time-use data, participants were asked to record their out-of-class Englishrelated time use for one week using a time diary (see Figure 1) developed for the 2011 study (Visgatis, 2014), which he called the English Access Time Use Survey (EATUS). In Visgatis' study, interview participants reported that completion of the form required only a few minutes each day. The EATUS solicited information about each episode, including the date and time, a description of the activity, two affective ratings about the activity (enjoyment and anxiety), the purpose of the episode, location where the activity transpired, and others present during the activity. Most participants wrote activity descriptions in Japanese or in a mixture of Japanese and English. Only a handful of participants during either study wrote exclusively in English. Participants in the studies reported here provided one to two weeks of data.

\section{Coding Time Use Data}

The episode description data collected using the EATUS form was coded by the researchers following the coding scheme developed by Visgatis (2014) (see Table 3). This coding was used to maintain consistency between studies. Participants' entries were first translated, then coded into sub-categories, which were then grouped. Codes were not mutually exclusive, meaning an entry coded for listening, such as listening to music, was

Figure 1

English Version of Time Diary Used in 2011 and 2018

\begin{tabular}{|c|c|c|c|c|c|c|c|c|c|c|c|c|c|c|c|c|c|c|c|c|c|}
\hline \multicolumn{2}{|c|}{ Date } & \multicolumn{2}{|c|}{ Start } & \multicolumn{2}{|c|}{ End } & \multirow[b]{2}{*}{ Activity } & \multirow[b]{2}{*}{ 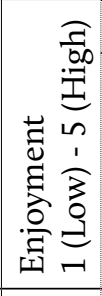 } & \multirow{2}{*}{ 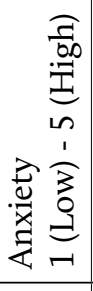 } & \multirow[b]{2}{*}{$\begin{array}{l}\overrightarrow{0} \\
\overrightarrow{0} \\
0 \\
\overrightarrow{0} \\
\overrightarrow{0}\end{array}$} & \multirow[b]{2}{*}{ 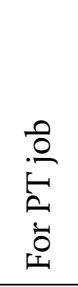 } & \multirow[b]{2}{*}{ 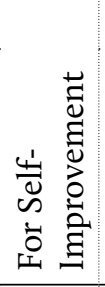 } & \multirow[b]{2}{*}{ 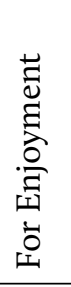 } & \multirow[b]{2}{*}{ 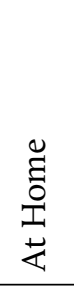 } & \multirow[b]{2}{*}{ 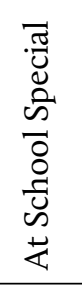 } & \multirow[b]{2}{*}{ 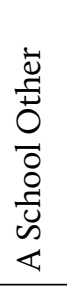 } & \multirow[b]{2}{*}{ 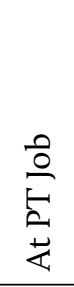 } & \multirow[b]{2}{*}{ 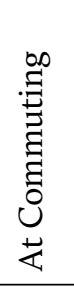 } & \multirow[b]{2}{*}{$\begin{array}{l}\dot{\vec{U}} \\
\stackrel{ \pm}{ \pm} \\
\dot{0} \\
\ddot{z}\end{array}$} & \multirow[b]{2}{*}{ 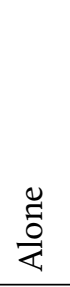 } & \multirow[b]{2}{*}{ 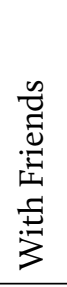 } & \multirow[b]{2}{*}{$\begin{array}{l}\dot{ \pm} \\
\dot{0}\end{array}$} \\
\hline $\mathrm{M}$ & $\mathrm{D}$ & $\begin{array}{l}\mathrm{H} \\
\mathrm{H}\end{array}$ & $\begin{array}{l}\mathrm{M} \\
\mathrm{M}\end{array}$ & $\begin{array}{l}\mathrm{H} \\
\mathrm{H}\end{array}$ & $\begin{array}{l}\mathrm{M} \\
\mathrm{M}\end{array}$ & & & & & & & & & & & & & & & & \\
\hline 6 & 14 & 16 & 50 & 17 & 01 & English cards & 4 & 4 & 1 & & & & 1 & & & & & & 1 & & \\
\hline 6 & 15 & 17 & 45 & 22 & 10 & Essay and journal writing & 4 & 4 & & & & 1 & 1 & & & & & & 1 & & \\
\hline 6 & 18 & 22 & 00 & 22 & 15 & Sent mail to foreigners & 4 & 1 & 1 & & & & 1 & & & & & & 1 & & \\
\hline 6 & 20 & 21 & 42 & 21 & 50 & Vocabulary cards & 4 & 1 & 1 & & & & & & 1 & & & & & 1 & \\
\hline 6 & 21 & 16 & 35 & 16 & 51 & Vocabulary cards & 4 & 1 & & & & & 1 & & & & & & 1 & & \\
\hline 6 & 28 & 16 & 25 & 16 & 40 & Vocabulary cards & 4 & 1 & 1 & & & & & & 1 & & & & 1 & & \\
\hline
\end{tabular}

Note. $\mathrm{M}=$ month, $\mathrm{D}$ = day, $\mathrm{HH}$ = hour, $\mathrm{MM}$ = minutes. In Japanese, one character was used (月, 日, 時, 分: month, day, hour, minutes). See Visgatis, 2014, for a Japanese version and an explanation of the development and validation of this instrument. From "English-related out-of-class time use by Japanese university students" by B. Visgatis, 2014, p. 663, [Unpublished doctoral dissertation]. Temple University. http://dx.doi.org/10.34944/dspace/3980 


\section{JALT2020}

COMMUNITIES OF

Visgatis \& Swenson: Motivational Change After Curricular Revision: Intersections With Out-of-Class Time Use coded into both listening and music, placing the entry into the " 4 Skills" and "Media \& Technology" categories. These codes were then used to determine how participants used their out-of-class time allocated to English for either personal or school-directed reasons.

Table 3

Coding for the Time Data Collected in 2011 and 2018

\begin{tabular}{llll}
\hline \multicolumn{1}{c}{ Category } & \multicolumn{1}{c}{ Sub-category } & \multicolumn{1}{c}{ Category } & \multicolumn{1}{c}{ Sub-category } \\
\hline 4 Skills & Listening & Media \& Technology & Application \\
& Reading & & Internet \\
& Speaking & & Music \\
\multirow{4}{*}{ Interaction } & Writing & & News \\
& Club & & Radio \\
& Contest & & Skype (or similar) \\
& Converse & \multirow{2}{*}{ Student } & Video \\
& Interview & & Course \\
& Support & & Homework \\
International & Teaching & & Prepare \\
& Culture & & Review \\
& Foreigners & & Study \\
& EIKEN & & Test \\
& TOEFL & Support Skills & Grammar \\
& TOEIC & & Pronunciation \\
& & & Vocabulary \\
\hline
\end{tabular}

Note. EIKEN = Test in Practical English Proficiency, TOEFL = Test of English as a Foreign Language; TOEIC $=$ Test of English for International Communication.

\section{Motivation Between Studies}

\section{Results and Discussion}

The motivational data for the participants $(N=794)$ were analyzed following the Rasch procedures outlined in Visgatis (2014) to determine if there were any significant differences between the 2011 and 2018 groups. As can be seen in Figure 2, the mean motivational level for the 2018 participants $(n=485)$ was less than that found for the 2011 participants $(n=309)$. The left scale indicates the motivation level, with a higher score indicating a greater degree of motivation. An analysis of variance (ANOVA) was conducted to assess whether the motivation levels differed significantly between studies. Levene's test of equality of Error Variances was not significant (.071). In short, there was no significant difference between the motivational profiles of participants in the two studies, $F(1,762)=3.092, p=.079, n s, \eta^{2}=.004$, which addresses RQ1.

Figure 2

Motivational Levels of 2011 and 2018 Participants

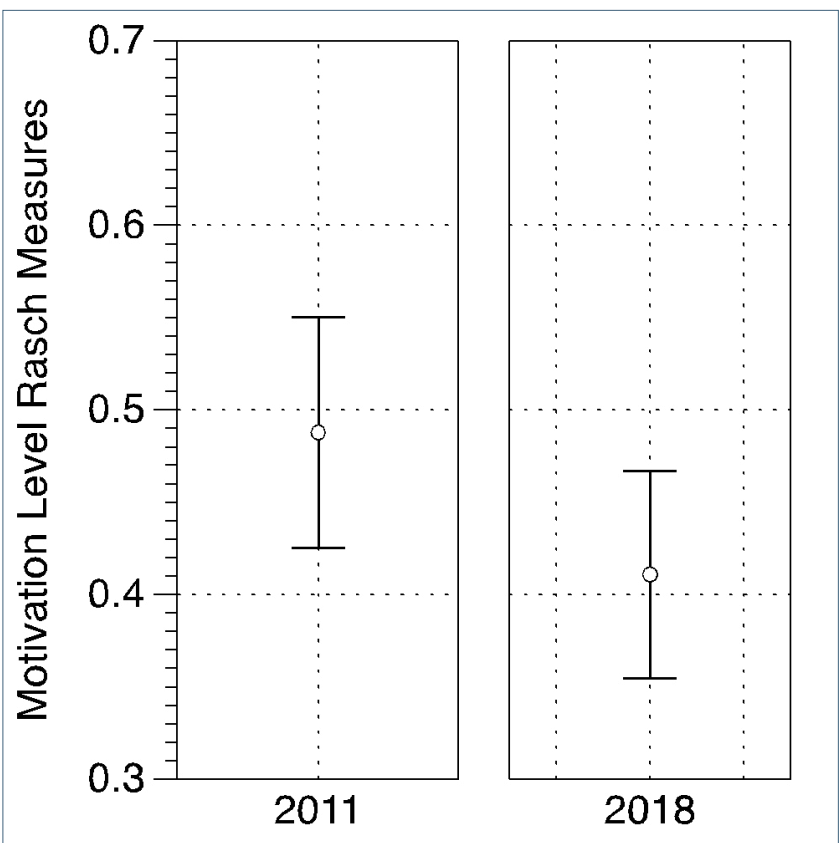

Note. $2011, n=309 ; 2018, n=485$ 
JALT2020

COMMUNITIES OF
TEACHERS \& IEARNERS

\section{Time Use Between Studies}

Participants in $2011(n=97)$ and $2018(n=174)$ spent approximately the same amount of time outside of class engaged with English. An ANOVA comparing the two cross sectional studies with minutes per day as the dependent variable and study as the independent variable indicated use of Welch's $t$-test, with effect size calculated using Cohen's $d$; this showed that the difference in time use for the two groups was not statistically significant, $t(165.772)=3.559, p=.061, n s, d=0.011$. Deficiencies in the data collection protocols made it difficult to determine whether days without recorded episodes were days without data or days without records. Two calculations were used for measuring minutes per week: one more conservative (Minutes per Day 1 ) and one more liberal (Minutes per Day 2). The true amount of time is likely to be somewhere between these. For this paper, we have adopted the more conservative formula. As such, the data indicate that time engaged with English decreased just under 8\% after the curricular changes. In temporal terms, that amounts to just over 3 minutes per day. Figure 3 displays the data using both formulas.

Figure 3

Two Calculations for Minutes per Day on English for Participants in 2011 and 2018

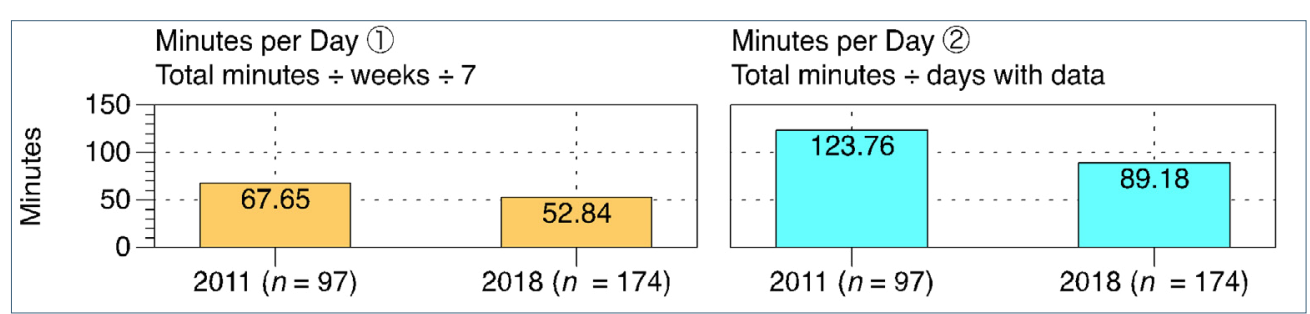

Note. Minutes per day were calculated in two ways: Minutes per Day $1=$ total minutes divided by number of weeks and number of days in study, Minutes per Day $2=$ total minutes divided by days with data entered.

The pattern of time use was similar during both studies (see Figure 4), as was the time allocation by the purpose of the activity (see Figure 5). Because of variations in participants' reporting of English use during part-time jobs, this category is excluded from this analysis. Figure 6 shows that there was little difference in the participants' average number of minutes coded for interaction over the two periods.
Figure 4

Time Allocation by Day of Week for 2011 and 2018

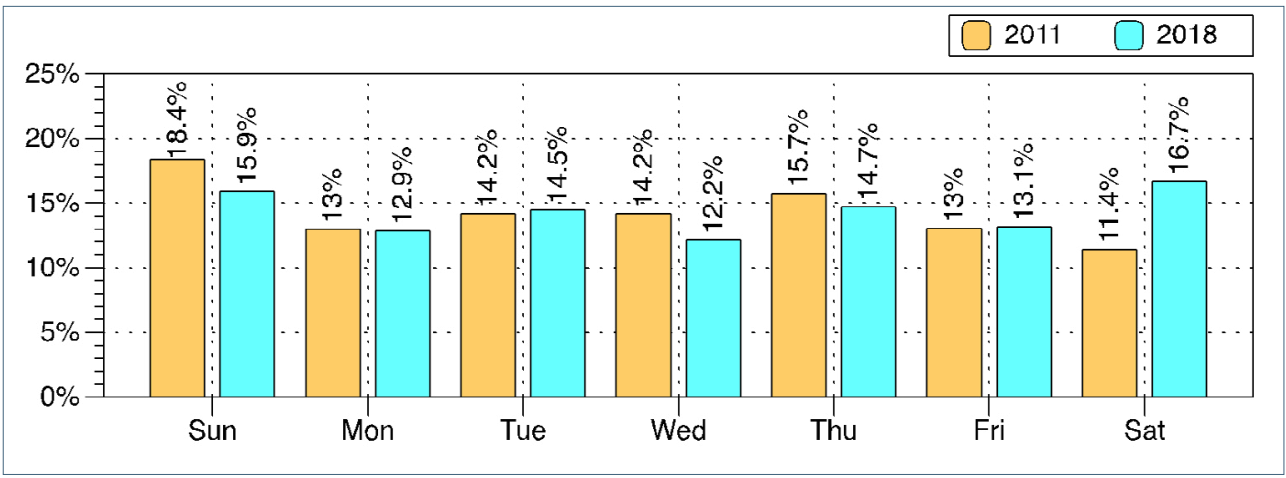

Note. 2011, $n=97 ; 2018, n=174 ;$ reported episodes in $2011=566$; reported episodes in $2018=$ 1068 .

Figure 5

Time Allocation by Purpose for 2011 and 2018 Participants

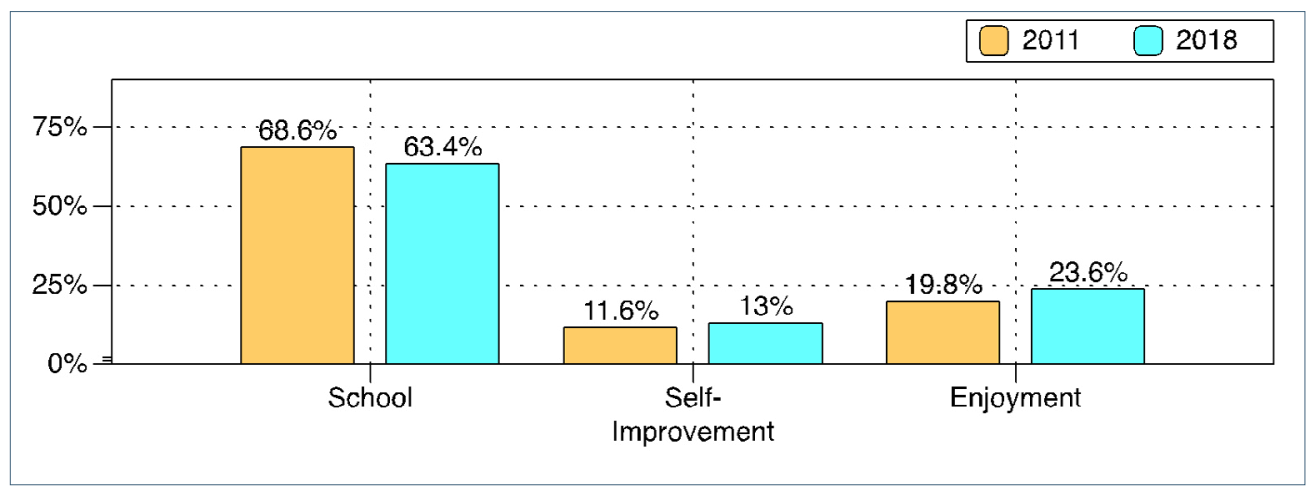

Note. 2011, $n=97 ; 2018, n=174$ 
JALT2020

COMMUNITIES OF
TEACHERS \& IEARNERS

\section{Figure 6}

Time Allocation by Activity for 2011 and 2018 Participants

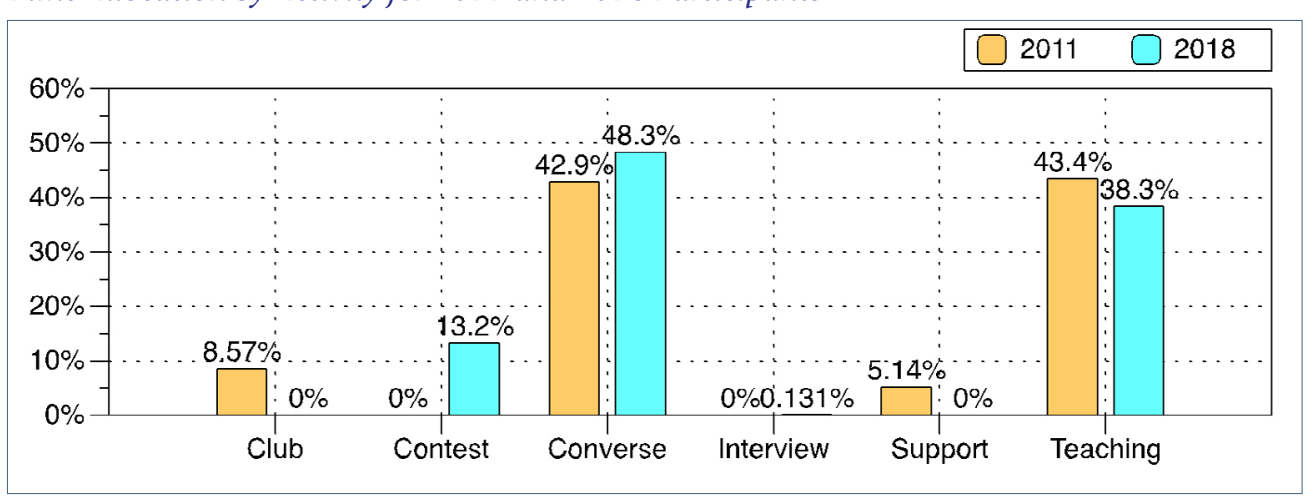

Note. $2011, n=97 ; 2018, n=174$.

However, the data showed that there was a shift in the time allocation by the 4-skill area identified in the coding (see Figure 7) and for the support skills (see Figure 8), which suggested that the curricular change led to a reallocation in the time devoted to each skill area.

Figure 7

Time Allocation by 4-skill area for 2011 and 2018 Participants

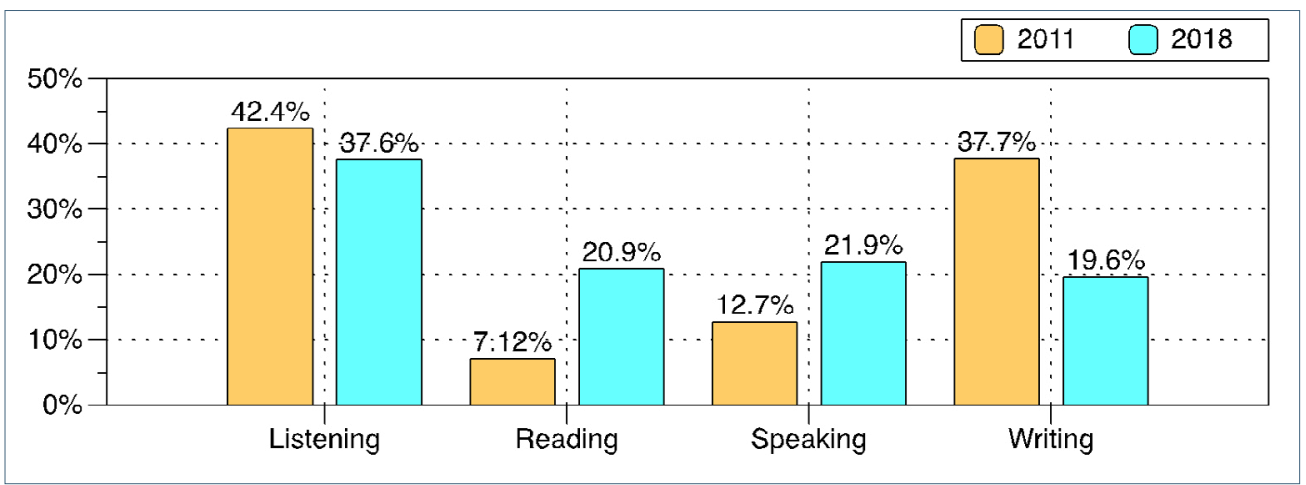

Note. $2011, n=97 ; 2018, n=174$
Figure 8

Time Allocation by Support Skill for 2011and 2018 Participants

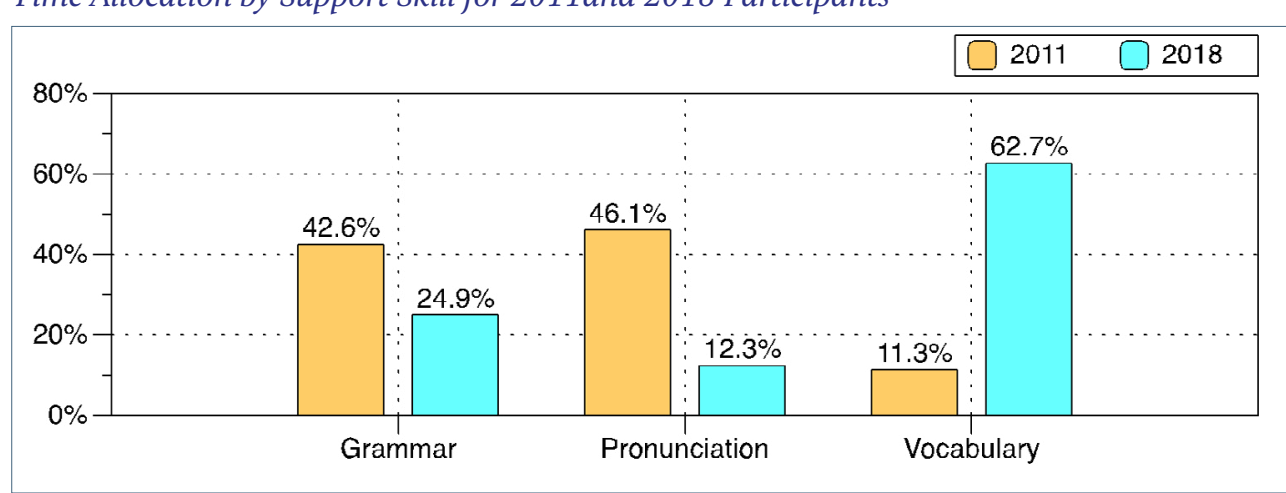

Note. $2011, n=97 ; 2018, n=174$.

The amount of out-of-class time allocated to school assignments, whether calculated as total time or number of episodes, indicates much of the English-related time-use is directed by the school curriculum. Approximately two-thirds of the minutes and two-thirds of the episodes were devoted to working on school-related assignments (see Figure 9).

Figure 9

Time Allocation in Proportion of Time (left) and Proportion of Episodes (right) for 2011and 2018 Participants

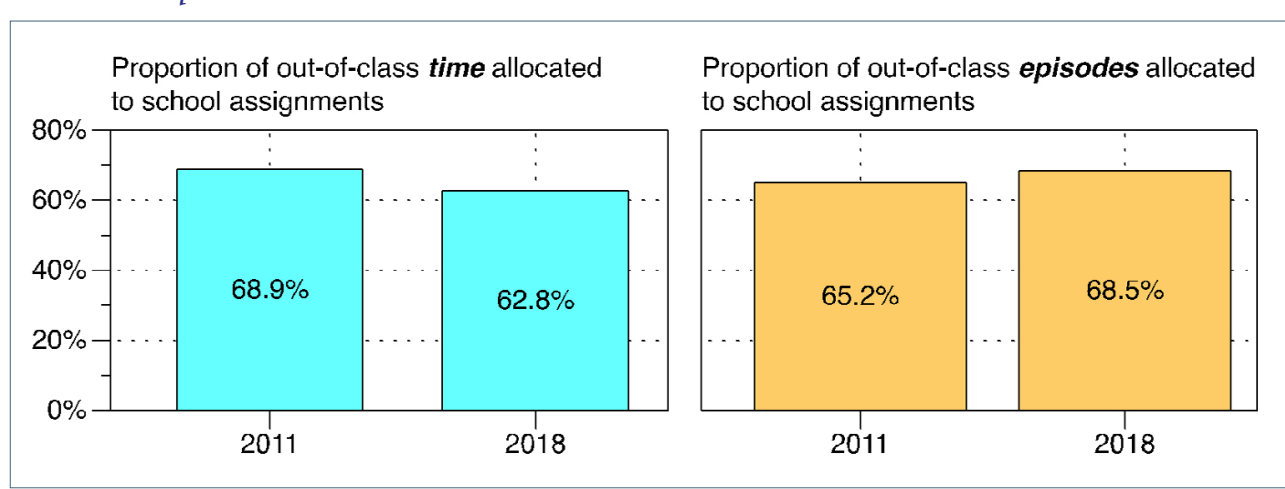

Note. $2011, n=97 ; 2018, n=174$ 
Intersections Between Time Use and Motivation Between Studies

A 1-tailed Pearson correlation between participants' $(n=271)$ motivational levels and out-of-class English time use showed a weak, but statistically significant positive correlation, between motivation and time use $(r=.116, p=.05)$ (see Figure 10).

Figure 10

Correlation between Motivation Levels and Time Use

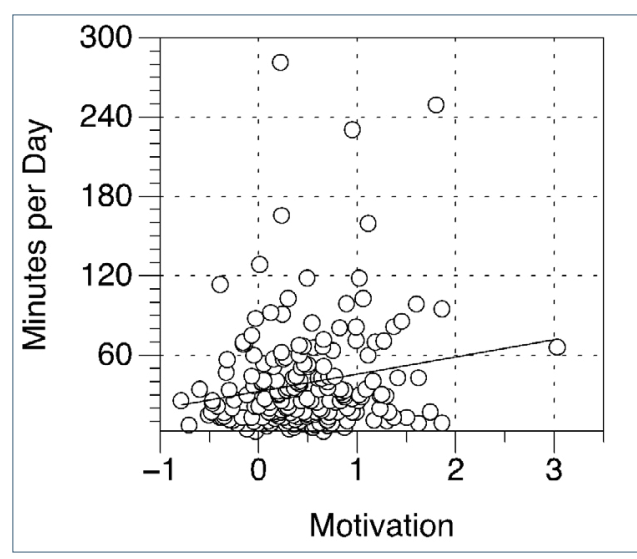

Note. A 1-tailed Pearson correlation showed positive correlation between motivation and time use for participants $(n=271) . r=.116 ; p<.05$

\section{Differences Between Studies}

Together, this information addresses research questions 2 through 4 and the hypothesis. First, the data indicate that students in 2011 and 2018 had similar patterns of time allocation to out-of-class English study (RQ2). Furthermore, when differences were found in the out-of-class time use by students between these two periods, they were driven by changes in the course requirements (RQ3), as seen in the shift of time to reading and vocabulary (see Figures $7 \& 8$ ) for the 2018 participants. This also addresses RQ4. As the discussion above indicated, no significant differences were found between the motivational levels of the participants in the two studies (RQ1). Finally, the data reject the hypothesis that curricular change would lead to students spending more time on out-of-class study in 2018 than those in 2011. There was no significant difference in time allocation.

\section{Time Use and MEXT Guidelines}

Research question 5 considered what proportion of students met the MEXT out-ofclass to in-class time ratio and whether there were differences between 2011 and 2018. Here, issues in participants' compliance with data collection procedures during both periods need to be addressed. The first issue was the lack of a reliable way to differentiate between days without English-related out-of-class time use and days with unreported data. Although the instructions to the students and the cooperating teachers, provided in Japanese and English, were considered clear by participants in pilot studies (see Visgatis, 2014), many of the participants in the 2011 and 2018 studies did not follow them. Moreover, although many participants faithfully completed all items for each activity episode, others did not. This led to discrepancies in the activity descriptions (e.g., homework) and the purposes (e.g., self-improvement), which made it difficult to clearly differentiate school-related from self-directed time use.

The second issue was that participants had to self-report the number of minutes of English classes they had in their weekly schedules as one of the items on the motivational survey. During the processing of survey data, it was apparent that the item was ambiguous in that it could be interpreted as asking for the number of minutes for (a) the course through which the survey had been conducted, (b) courses that were Englishlanguage courses, (c) all courses (English and content) in which English was the language of instruction, (d) some combination of these, or (e) classes taken outside the university. In fact, the totals reported for English course minutes were often vastly different from what could be expected given the curriculum and required courses at the institution.

Given the above caveats, only speculative results concerning how well participants met MEXT (2009) guidelines for courses can be presented. Nevertheless, we feel that this information is important and useful for advancing the discussion regarding possible benefits and outcomes for curricular revision. For both studies, less than $15 \%$ of the participants met the 2:1 MEXT ratio and approximately $1 / 3$ met a more relaxed ratio of 1:1 (RQ5). As these totals include all episodes types, excluding part-time jobs as discussed above above, and not only those related to homework or class preparation, they overestimate the number of participants meeting the standard. Furthermore, as the percentage of all episodes with activity descriptions indicates time related to schoolwork (e.g., homework) is $65.97 \%$, we can expect the true numbers to be much less (see Table 4 ). 
JALT2020

COMMUNITIES OF
TEACHERS \& LEARNERS

Table 4

Proportion of Students Meeting MEXT Out-of-Class Study Ratio for All Episodes

\begin{tabular}{lcc}
\hline & 2011 & 2018 \\
\hline $\begin{array}{l}\text { Number of participants with time use and English class minute } \\
\text { data }\end{array}$ & 44 & 128 \\
Percentage meeting the 1:1 ratio & $31.8 \%$ & $36.3 \%$ \\
Percentage meeting the 2:1 ratio & $13.6 \%$ & $10.2 \%$ \\
\hline
\end{tabular}

Follow-up studies should be conducted to confirm these results. In such cases, changing from paper to digital collection may reduce the amount of missing data, improve compliance, and increase reliability.

\section{Limitations}

One limitation was the data-entry burden placed on participants, which was the most likely cause of incomplete data sets. Though Visgatis' (2014) reports from interview participants indicated the form was easy to complete, these participants maintained time data for an entire semester. The problem did not seem to be one of completing the form but that of remembering to do so. This is a problem that time use researchers have noted with other time use data collection instruments (e.g. Chatzitheochari et al., 2018; Harvey, 1993; Hektner et al., 2007; Pentland et al., 1999). A second limitation was the instrument itself. There was no place to indicate "no episodes." Having this would have allowed researchers to determine if a day with no data reported was one with no episodes or was a day where the participant skipped reporting them. A third limitation was environmental; students often studied for classes late in the evening, which might have influenced the accuracy of reporting.

\section{Conclusions}

The results indicate that the motivational levels of participants toward English showed no significant change between the 2011 and 2018 participants. This may not be surprising given that the participants had already self-selected into a rigorous Englishintensive curriculum.
Moreover, results also indicate that while curricular changes exert a great effect on what occurs during class time, the impact on out-of-class time may be less direct and predictable. It appears that there is a relatively stable limit to the amount of time participants are willing to spend engaged with English outside of class. Although curricular change might redirect students' focus, as seen in the reallocation of time to vocabulary study or reading in the data provided, this does not necessarily lead to an increase in time allocated to out-of-class English study. That participants in 2018 spent more time on study of vocabulary and on reading was not surprising given that both became required components. However, the decrease in time allocated to other skills, which remained required components, was not what the curriculum developers expected. Clearly, program administrators need to be aware that out-of-class time use by students may be relatively stable and unlikely to increase following curricular changes. Teachers also need to be aware that the amount of time students spend on out-of-class study is unlikely to change unless there are required components that must be completed outside of class hours.

Furthermore, the results, along with those obtained by Visgatis (2014) for a larger population of students, indicate that expectations regarding student out-of-class time devoted to courses are rarely met. This suggests the need to reconsider governmental guidelines in light of actual student behavior or radically change the demands for out-ofclass study. The reality is that time is a constant: 24 hours a day, 168 hours a week. When all the demands on students' time, particularly that of part-time jobs, are considered, the appropriate response might be striking a balance. If students must work to afford an education, the time they can spend on that education is curtailed.

Although studies of time use face numerous challenges, technological advances might provide avenues for collecting accurate time use data. Chatzitheochari et al (2018) recommend researchers employ web and app modes for data collection, which they found provided more accurate results. These tools might also allow for a clearer understanding of how time is used beyond amounts. Another avenue for research is to examine time use on English by a wider variety of majors, as this study only examined participants in an English-intensive program. Furthermore, examination of all out-ofclass study seems warranted to fully understand how students allocate time to their education. Finally, curriculum developers should probably compare time use data from before and after curricular revisions to assess their impact. 
JALT2020

COMMUNITIES OF
TEACHERS \& LEARNERS

\section{Bio Data}

Brad Visgatis is a professor at Osaka International University. His research interests are motivation, comparative media, and research methods. Contact <b.visgatis@gmail.com>

Tamara Swenson is a professor at Osaka Jogakuin University, where she is also director of international programs. Her research is focused on aspects of media and media use. Contact $<$ t1swenson@wilmina.ac.jp >

\section{References}

Boo, Z., Dörnyei, Z., \& Ryan, S. (2015). L2 motivation research 2005-2014: Understanding a publication surge and a changing landscape. System, 55, 145-157. http://dx.doi.org/10.1016/j. system.2015.10.006

Busse, V., \& Walter, C. (2013). Foreign language learning motivation in higher education: A longitudinal study of motivational changes and their causes. The Modern Language Journal, 97(2), 435-456. https://doi.org/10.1111/j.1540-4781.2013.12004.x

Chatzitheochari, S., Fisher, K., Gilbert, E., Calderwood, L., Huskinson, T., Cleary, A., \& Gershuny, J. (2018). Using new technologies for time diary data collection: Instrument design and data quality findings from a mixed-mode pilot survey. Social Indicators Research, 137, 379-390. https://doi.org/10.1007/s11205-017-1569-5

Cline, W., Cornwell, S., Fukushima, C., Hirano, M., Johnston, S., McLean, S., Takezawa, Y., \& Tojo, K. (2017). Empowering low-English-proficiency students: A fresh approach. Osaka Jogakuin University Research Journal, 13, 85-105. http://ir-lib.wilmina.ac.jp/dspace/ bitstream/10775/3428/1/B_06Cornwell.pdf

Dörnyei, Z. (2009). The L2 motivational self system. In Z. Dörnyei \& E. Ushioda (Eds.), Motivation, language identity and the L2 self (pp. 9-42). Multilingual Matters.

Dörnyei, Z., Henry, A., \& Muir, C. (2015). Motivational currents in language learning: Frameworks for focused interventions. Routledge.

Harvey, A. S. (1993). Guidelines for time use data collection. Social Indicators Research, 30, 197-228. https://www.doi.org/10.1007/BF01078728

Hektner, J. M., Schmidt, J. A., \& Csikszentmihalyi, M. (2007). Experience sampling method: Measuring the quality of everyday life. Sage.

Hyland, F. (2004). Learning autonomously: Contextualising out-of-class English language learning. Language awareness, 13(3), 180-202. https://doi.org/10.1080/09658410408667094

Kuh, G. D. (1995). The other curriculum: Out-of-class experiences associated with student learning and personal development. The Journal of Higher Education, 66(2), 123-155. https://doi.org/10.10 $80 / 00221546.1995 .11774770$
Kramer, B., Matsuo, T., McLean, S., \& Cornwell, S. (2019). Measuring attrition of L2 receptive vocabulary knowledge over the summer vacation. Verb, 8(1), 17-22. https://brandonkramer.net/ pdf/2019_VERB_vocabAttrition.pdf

Lyddon, PA, \& Kramer, B. (2019). Connecting extensive reading to TOEIC performance. In F. Meunier, J. Van de Vyver, L. Bradley \& S. Thouësny (Eds.), CALL and complexity-short papers from EUROCALL 2019 (pp. 257-262). Research-publishing.

McCarty, S., Sato, T., \& Obari, H. (2017). Osaka Jogakuin University case study: Mobilizing the EFL curriculum and campus infrastructure with iPods and iPads. In S. McCarty, H. Obari, \& T. Sato, T. (Eds.) Implementing mobile language learning technologies in Japan (pp. 57-69). Springer.

McLean, S., Hogg, N., \& Rush, T. W. (2013). Vocabulary learning through an online computerized flashcard site. JALT CALL Journal, 9(1), 79-98. https://files.eric.ed.gov/fulltext/EJ1108008.pdf

Ministry of Education, Culture, Sports, Science and Technology (MEXT). (2009). Quality assurance framework of higher education in Japan. Higher Education Bureau MEXT. https://www.mext. go.jp/en/policy/education/highered/title02/detail02/1373877.htm

Nakata, T., Tada, S., Mclean, S., \& Kim, Y. A. (2020). Effects of distributed retrieval practice over a semester: Cumulative tests as a way to facilitate second language vocabulary learning. TESOL Quarterly, 54(2), 1-23. https://doi.org/10.1002/tesq.596

Nation, I. S. P., \& Waring, R. (2019). Teaching extensive reading in another language. Routledge.

Oga-Baldwin, W. Q., \& Fryer, L. K. (2020). Profiles of language learning motivation: Are new and own languages different? Learning and Individual Differences, 79, 1-13. https://doi.org/10.1016/j lindif.2020.101852

Pentland, W. W., Harvey, A. S., Lawton, M. P. \& McColl M. A. (Eds.). Time use research in the social sciences. Klewer Academic/Plenum.

Swenson, T., Bramley, D., \& Cornwell, S. (2014). Making interactive eBooks: More than just cutting and pasting. Osaka Jogakuin University Research Journal, 10, 17-30. http://ir-lib.wilmina.ac.jp/ dspace/bitstream/10775/3127/1/B_02Swenson.pdf

Ushioda, E. (2011). Language learning motivation, self and identity: Current theoretical perspectives. Computer Assisted Language Learning, 24(3), 199-210. https://doi.org/10.1080/09 588221.2010 .538701

Ushioda, E. (2020). Language learning motivation. Oxford University Press.

Visgatis, B. (2014). English-related out-of-class time use by Japanese university students [Unpublished doctoral dissertation]. Temple University. http://dx.doi.org/10.34944/dspace/3980

Woodrow, L. (2017). Motivation in language learning. Springer. 